\title{
Spontaneous closure of macular hole after pars plana vitrectomy: report of two cases
}

\author{
Fechamento espontâneo de buraco de mácula em olhos \\ previamente vitrectomizados: relato de dois casos
}

Ana Claudia de Franco Suzuki', Leandro Cabral Zacharias', Mário Junqueira Nóbrega², Rony Carlos Pretti', Walter Yukihiko Takahashi ${ }^{1}$

\begin{abstract}
The spontaneous closure of a full-thickness macular hole (MH) developed after vitrectomy is very uncommon. We report a small series of cases (two patients) with this presentation. The first patient developed a MH 1 month after vitrectomy for an epirrretinal membrane and, the second one, 3 weeks after vitrectomy for rhegmatogenous retinal detachment. The MHs resolved spontaneously 2 months and 1 month after their documentation by optical coherence tomography(OCT), respectively. In this case report, we review the literature on spontaneous closure of MHs and discuss possible mechanisms for this rare event.

Keywords: Retinal perforations, Vitrectomy/methods, Optical coherence tomography, Epiretinal membrane, Retinal detachment, Case reports
\end{abstract}

\section{Resumo}

O fechamento espontâneo de buraco de mácula de espessura total é um fenômeno raro, especialmente em olhos vitrectomizados. Descrevemos nesse relato dois casos com essa apresentação. No primeiro caso, notou-se o buraco de mácula 1 mês após vitrectomia por membrana epirretiniana e, no segundo, 3 semanas após vitrectomia por descolamento de retina regmatogênico. O fechamento desses buracos ocorreu espontaneamente 2 meses e 1 mês após sua documentação, respectivamente. Feita a revisão bibliográfica e propostas teorias para explicar esta evolução atípica, o entendimento deste fenômeno pôde nos ajudar a refinar a indicação cirúrgica desta patologia.

Descritores: Perfurações retinianas, Vitrectomia/métodos, Tomografia de coerência óptica, Membrana epirretiniana, Descolamento retiniano, Relatos de casos

\footnotetext{
${ }^{1}$ Medical School of the São Paulo University, São Paulo/SP, Brazil.

${ }^{2}$ University of the Joinville Region, Joinville/SC, Brazil.
}

Work conducted the Ophthalmology Unit, Medical School of the São Paulo University, São Paulo/SP, Brazil.

The authors declare no conflicts of interest

Received for publication: 4/2/2013 - Accepted for publication: 22/9/2013 


\section{INTRODUCTION}

$\mathbf{I}$ diopathic macular hole (IMH) was first described in the late $19^{\text {th }}$ century and it typically occurs in women in their sixth or seventh decade of life.Gass et al.suggested in 1988 that the condition could be linked to traction of the posterior vitreous surface and proposed a classification according to its biomicroscopic features(Table 1). Stages 1A (early macular hole) and $1 \mathrm{~B}$ (occult) were subsequently included in this classification. ${ }^{1}$

Approximately $50 \%$ of stage 1 macular holes (MHs) resolveafter spontaneous vitreous-foveal separation.Most stage $2 \mathrm{MHs}$ progress to stages 3 and 4, as shown byKim et al. in a prospective, randomised study on 21 eyeswith stage $2 \mathrm{MH}$, where $71 \%$ progressed to later stages. ${ }^{2}$

Pars plana vitrectomy (PPV) for closing IMH was first described by Kelly and Wendel in $1991^{(3)}$.Surgical treatment is currently indicated in cases of full-thickness IMH, and more than $90 \%$ of cases resolve with surgery, with visual acuity improving in up to $70 \%$ of cases. ${ }^{4}$

Duration of symptoms, MH size, preoperative visual acuity (VA), and the ratio between $\mathrm{MH}$ rim and diameter on OCT are factors that affect the visual prognosis after vitrectomy.The postoperative integrity of the photoreceptor layer is also important for the functional outcome. ${ }^{5}$

Spontaneous closure of full-thickness IMH is rare, with a reported prevalence of $4-6 \%$.Spontaneous closure is more common in traumatic MH (especially in young patients).Suggested mechanisms include spontaneous release of vitreous traction; epiretinal membrane (ERM) contraction; glial or retinal pigment epithelial proliferation; or retinal tissue bridging, forming a framework that closes the hole. ${ }^{6}$

MH relapse after vitrectomy occurs in 4.5 to $9.5 \%$ of cases. ${ }^{7}$ Spontaneous closure is rare, as the vitreous traction component is no longer present.This phenomenon is even more uncommon in MHs found after PPV due to other retinal conditions. ${ }^{8}$

This paper will describe two cases of full-thickness $\mathrm{MH}$ occurring after vitrectomy that resolved spontaneously.

Case 1

Male, 62-year-old patient with progressive loss of VA in the left eye (LE) for 6 months.Corrected VA was 20/60 in the

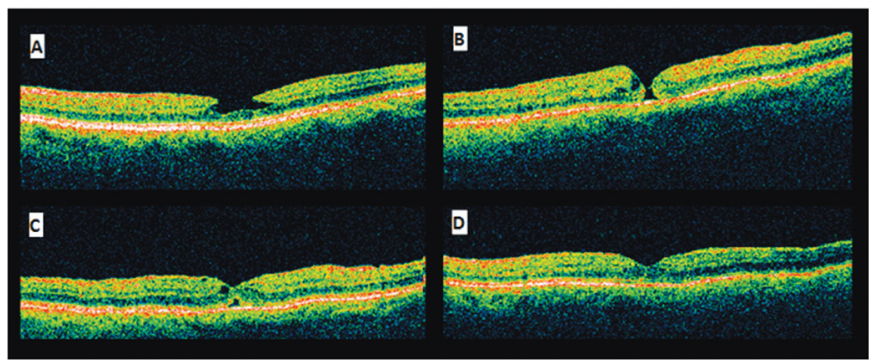

Figure 1: Preoperatively (A):ERM + lamellar macular hole; 1 month after surgery (B):full-thickness macular hole; 3 months after surgery (C):tissue bridge; 5 months after surgery:no macular abnormalities

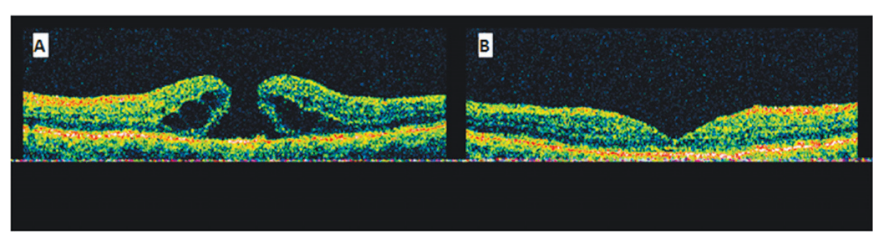

Figure 2: Three weeks after PPV (A), full-thickness MH; 7 weeks after PPV (B), spontaneous closure of the MH

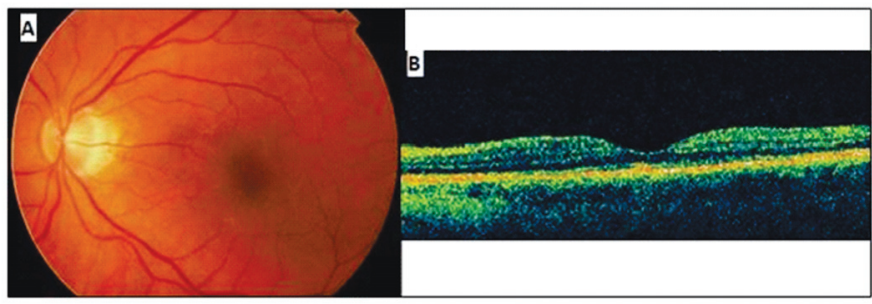

Figure 3: Retinography (A) and OCT (B) after 1 year of follow-up

LE; retinal mapping found macular folds and an image suggestive of MH.The Watzke-Allen test was negative, and OCT found a lamellar MH (Figure 1A).PPV was performed to remove the ERM and the internal limiting membrane followed by air tamponade, without complications.

One month after surgery the patient complained of a central scotoma in the LE.His VA was 20/50, with a positive WatzkeAllen test and OCT showing a full thickness macular microhole

Table 1

\section{Stages of macular hole according to the Gass classification}

\begin{tabular}{lll}
\hline Staging & \multicolumn{1}{c}{ Biomicroscopic Features } \\
\hline 1 & 1A & $\begin{array}{l}\text { Loss of foveal depression and presence of a yellow spot in the fovea, loss of normal foveal reflex, } \\
\text { no posterior vitreous detachment } \\
\text { Loss of foveal depression, yellow ring with bridging interface of vitreous cortex, no posterior vitreous } \\
\text { detachment }\end{array}$ \\
2 & $\begin{array}{l}\text { Small central full-thickness retinal defect, with or without pre-foveal opacity (pseudo-operculum) } \\
\text { formed by the contracted pre-foveal cortical vitreous, no posterior vitreous detachment } \\
\text { Central full-thickness retinal defect with a diameter greater than or equal to 400im, elevated rim; } \\
\text { posterior vitreous still attached,no Weiss ring,with or without pre-foveal opacity (pseudo-operculum) } \\
\text { Central full-thickness retinal defect with a diameter greater than or equal to 400 ìm, elevated rim; detached } \\
\text { posterior vitreous (a Weiss ring is frequently observed) }\end{array}$ \\
\hline
\end{tabular}

Source:Translated and adapted fromGass JD.Reappraisal of biomicroscopic classification of stages of development of a macular hole.Am J Ophthalmol. 1995;119(6):752-9. 
(Figure 1B).The patient did not want to undergo a new procedure for personal reasons. Three months after surgery his correctedVA was 20/25, and OCT found a tissue bridge over the $\mathrm{MH}$, opening only in the deeper layers (Figure 1C).Five months after surgery the patient had no complaints, his correctedVA was 20/20, and his macula showed no abnormalities (Figure 1D).

\section{Case 2}

Female 44-year-old patient with myopia (-6 dioptres) and a history of radial keratotomy with a corrected VA of 20/25 in both eyes.She presented with an acute loss of vision in the LE (finger count at 2 metres), being diagnosed with rhegmatogenous retinal detachment with upper peripheral tears, being submitted to PPV.

Three weeks after the procedure her VA was 20/300 in the LE, and a full-thickness MH with intraretinal cysts was observed (Figure 2A). One month later, the $\mathrm{MH}$ resolved spontaneously and her VA improved to 20/50 (Figure 2B).After one year her VA remained unchanged (Figure 3).

\section{Discussion}

Spontaneous closure of a $\mathrm{MH}$ is rare but well described in the literature, and it is probably secondary to the release of vitreous traction due to spontaneous posterior vitreous detachment or glial proliferation. Retinal tissue bridging is especially important in cases of small MHs. ${ }^{6}$

Inoue et al. ${ }^{6}$ observed that the macular anatomy returned to normal within 3 years of follow-up in 6 patients with spontaneous MH closure assessed with OCT.VA improved in all patients, but with a worse final VA in cases of persistent foveal detachment after $\mathrm{MH}$ closure or delayed restoration of the inner and outer photoreceptor layers.

Recurrent MH after vitrectomy is uncommon and it rarely resolves spontaneously.Vitreomacular traction would not be an important causal factor in such cases, as the posterior vitreous would already be detached.In 2011 Yonekawa et al. ${ }^{9}$ reported the spontaneous closure of a recurrent myopic $\mathrm{MH}$ after vitrectomy.The authors describe another 5 cases of full-thickness $\mathrm{MH}$ after vitrectomy that resolved spontaneously, three of which were associated with ERM.

In MHsresolving spontaneously after vitrectomy for retinal conditions, the process could be related to degeneration of the inner retinal layers due toatrophy or coalescence of cystoid oedema.Proliferation and contraction of retinal glial elements could cause these MHs to increase in size. ${ }^{10}$

Ogawa et al. ${ }^{11}$ reported a MHarising 7 months after PPV due to ERM.Expectant management was adopted, as the patient had a good VA.Spontaneous closure of the MH occurred 2 months after diagnosis (OCT showed residual foveal detachment, which disappeared after a month).

In a case series, Tsilimbaris et $a .^{8}$ reported three $\mathrm{MHs}$ that resolved spontaneouslyin vitrectomised eyes:one due to penetrat- ing trauma and two due to retinal detachment.The MHs were diagnosed 14 months, 10 days, and 2 months after PPV, respectively,and spontaneous resolution occurred 2 years, 6 months, and 9 months after diagnosis.

These reports show that spontaneous $\mathrm{MH}$ closure in vitrectomised eyes is a rare but possible phenomenon.In one of the cases, retinal tissue bridging was observed, with initial closure of the inner retinal layers followed by the outer layers.Understanding these phenomena can help clarify the genesis of IMH, thus improving surgical indications and surgical techniques.

\section{ReFERENCES}

1. Gass JD. Reappraisal of biomicroscopic classification of stages of development of a macular hole. Am J Ophthalmol. 1995;119(6):752-9.

2. Kim JW, Freeman WR, Azen SP, el-Haig W, Klein DJ, Bailey IL. Prospective randomized trial of vitrectomy or observation for stage 2 macular holes. Vitrectomy for Macular Hole Study Group. Am J Ophthalmol. 1996;121(6):605-14.

3. Kelly NE, Wendel RT. Vitreous surgery for idiopathic macular holes. Results of a pilot study. Arch Ophthalmol.1991;109(5):654-9.

4. Bainbridge J,Herbert E, Gregor Z. Macular holes: vitreoretinal relationships and surgical approaches. Eye (Lond). 2008;22(10):1301-9. Review.

5. Negretto AD, Gomes AM, Gonçalves FP, Jiun HS, Abujamra S, Nakashima Y. [Use of anatomical measures of idiopathic macular hole obtained through optical coherence tomography as a predictive factor in visual results: a pilot study]. Arq Bras Oftalmol. 2007;70(5):777-83. Portuguese.

6. Inoue M, Arakawa A, Yamane S, Watanabe Y, Kadonosono K. Longterm outcome of macular microstructure assessed by optical coherence tomography in eyes with spontaneous resolution of macular hole. Am J Ophthalmol. 2012;153(4):687-91.

7. Gross JG. Late reopening and spontaneous closure of previously repaired macular holes. Am J Ophthalmol. 2005;140(3):556-8.

8. Tsilimbaris MK, Gotzaridis S, Charisis SK, Kymionis G, Christodoulakis EV.Spontaneous closure of macular holes developed after pars plana vitrectomy. Semin Ophthalmol. 2007;22(1):39-42.

9. Yonekawa Y, Hirakata A, Inoue M, Okada AA. Spontaneous closure of a recurrent myopic macular hole previously repaired by pars plana vitrectomy. Acta Ophthalmol. 2011;89(6):e536-7.

10. Lo WR, Hubbard GB. Macular hole formation, spontaneous closure, and recurrence in a previously vitrectomized eye. Am J Ophthalmol. 2006;141(5):962-4.

11. Ogawa M, Ohji M. Spontaneous closure of a macular hole after vitrectomy for an epiretinal membrane. Jpn J Ophthalmol. 2010;54(4):368-70.

\section{Corresponding author:}

Leandro Cabral Zacharias

Universidade de São Paulo, Faculdade de Medicina.

Av. Dr Eneas de Carvalho Aguiar, 255, $6^{\circ}$ Andar

Cerqueira Cesar

05403-000 - Sao Paulo, SP - Brazil

Telephone: (011) 30697871

Email: Iczacharias@gmail.com 